\title{
癌の代謝改善にかんする研究
}

\author{
特にグルクロン酸代謝をめぐつて

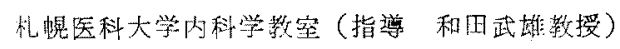 \\ 石井禎 郎

\section{STUDIES ON IMPROVEMENT OF METABOLIC CHANGES IN MALIGNANCIES. ESPECIALLY IN REGARD OF GLUCURONIC ACID METABOLISM} \\ Yoshirô IsHII \\ Department of Internal Medicine, Sapporo Medical College \\ (Director: Prof. Takeo Wada)
}

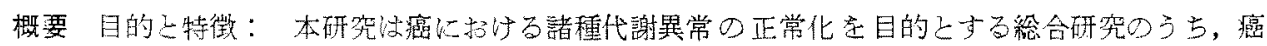

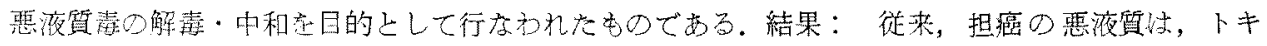

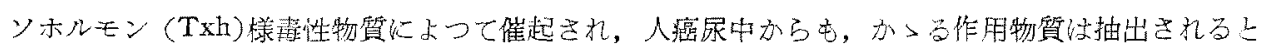

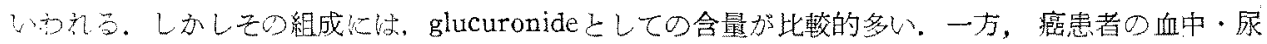

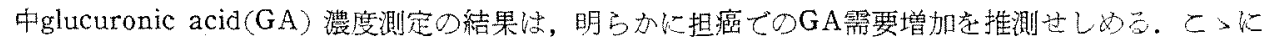

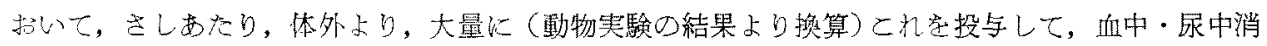

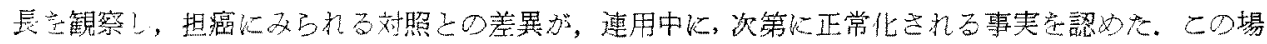

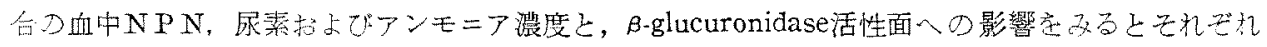

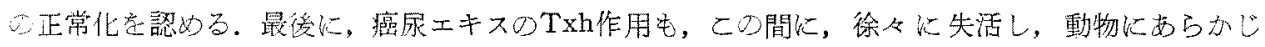

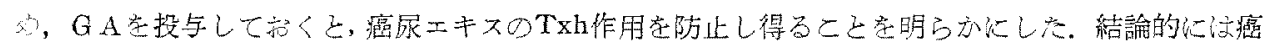

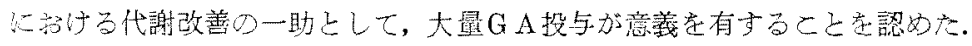

\section{耀}

悪性腫癔に㧍ける代謝異常は, anaerobic glycolysisの亢谁や，いわゆるnitrogen trapなる特 徽寺すとしても，これは，あくまでも対服との 䦥:量的考あるい惊度差の範囲を出ず，本質的

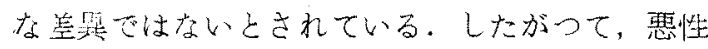

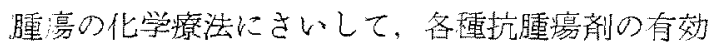

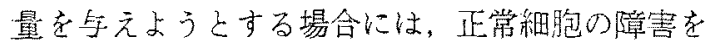
兔れ得す，副作用的全身反店の随伴㤎必尞する。

一子，担癌生体の代謝翼常の原因の一つには， 心的ゆる癌毒性物質の存在と，元の影響が考えら

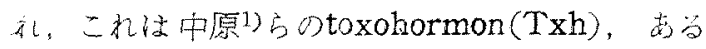
いは，それと類緣の癌瑇䇣到の追求によつて明
らかにされている。

こ〉において, 癌の一般治療には, その悪液賀 の改善に目学向的る上共に、癌表素の解毒，ある

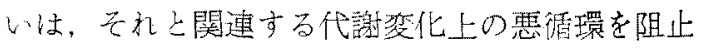
する試みが必要と考えられる。

中川放力Txh作用を有する尿エキスを分析す ると, hexosaminepglucuronic acid (GA) 含量

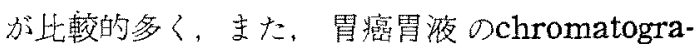
phyによるTxh作用含有画分についても，蛋白成 分に此較して精質成分が多い子同㭙に，GAの增 量が指摘さされている。これらのこと加ら, 担癌 生体内には，aglucuronとして多くの毒性物質が 含まれることが推測され，GA-conjugatesとして 
処理される可能性が推測される。

癌について、動物寒験上，体外加ら GA を与え た場合の影裝ならびに意義について新保らは， 吉田肉腫，Ehrlich腹水癌西るいは DAB䀒癌に おいて著明な発育小らでに発癌抑制效果を認め，

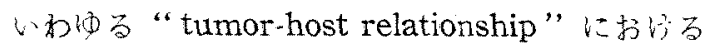

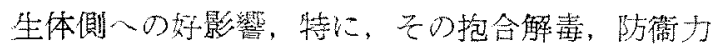
增強，あるいは代新改善面八の間接作用によるも のと推諭した。

こ、に括いて, 臨床的に癌にお打るGA代謝, 特に，その焦荷实験上の需給関係，およびここれ らを与えたさいの沓エキスのTxh作用面に見ら れる影響等を検討すぺく，本研究を進めた。

\section{実験方法}

\section{I. 対象}

骨癌29例を主とする癌33例と健康成人15例を選

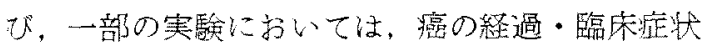
の総合判断により，此較的初期㾂らびに中期癌上 末期癌の 2 群に分けた。

II. 血中GA广らじに层中glucuronide (GLN) の測定

前者については，静脈血 $1 \mathrm{ml} k$ ¿aq.dest. $5.0 \mathrm{ml}$ を加えて楁血， $\quad 0.3 \mathrm{~N} \mathrm{Ba}(\mathrm{OH})_{2} 2 \mathrm{ml}$ 㧈よで5\% $\mathrm{ZnSO}_{4} 2 \mathrm{ml}$ 加えて除蛋白し, 系の㯖液について GA濃案測定した。

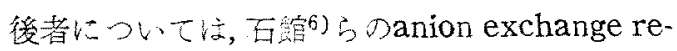

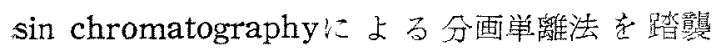
乙，遊離GA，抒よひ，N-GLN $(F+N-G)$ 函分 LO-GLN (O-G) 画分方分離測定した。測定は経

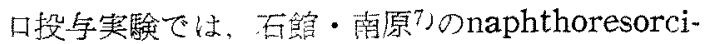
nol picrate (NRP) 法を用いたが，その後，GA 測定の基本的吟味の結果, Dische ${ }^{3)}$ Dcarbazole

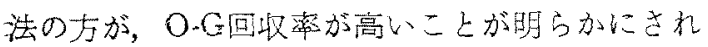
たので，非経口投与実験については、すへてこ礼 を用いた。

III. その他二，三血中成分の測定

血清 N P Nはmikrokjehldal法により，同尿素 はdiacethylmoxime法，また，血中ammoniaは
Seligson-Hirahara ${ }^{9}$ 法により測定した。血清 $\beta$-glucuronidase $(\beta-G)$ 活性 glucuronideを基質上する蒙元法间によつた。

VV. 尿エキスの抽出, ならびに, そのTxh作 朋の吟味

中川的の安息香酸吸着法を改息した福田11の力 法により，尿エキスを精製した。スのTxh作用 は，食慨その他の飼育条件を一定にした雄dd系マ ウスに対する眝catalase活性低下作用をみたが， 层エキ又は2.0mgをaq.dest. $0.5 \mathrm{ml}$ 亿溶解，腹照 内に注射し，24時間目の同活性低下度定小菅 ${ }^{22} の$ 方法で測定し，そのつに゙，对算と此較する方法を

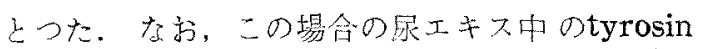
(Folin \& Ciocaltau法), hexose (orcinol- $\mathrm{H}_{2} \mathrm{SO}_{4}$ 法)およびGA (carbazole法) 量を測定した。

V. GA 偩荷案験

1) 経口顀荷法：早朝空䐓時にlactone型 GA $5 \mathrm{~g}$ 妾服用过し力，又心前已後 $1 ， 2 ， 3$ ，およ

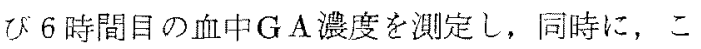
の实験前捘各 6 時閒の症中 G LN 量を測定した。 次いで，1遮間GA投与を続けて，8日目に同様

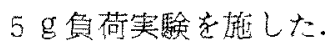

2) 非経口負荷法：この場合は新保5の動物 实駼の結果と、これまで教宝で種々検討した静注 量念の結果を参考七して，5\%sod. glucuronate (GA-Na) $500 \mathrm{ml}$ 正確に1時間にわたり点滴静

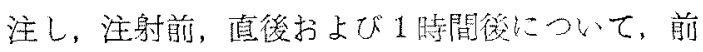
述同様血中 GA 抒よげ尿中 GLNを測定した。

これらのGA真荷前後においてGA以外の二, 三の血中成分の消長を検討し，尿工キスのTxh 作用の变動を叭昧した。

\section{実験成績}

I 。血中 GA 濃度ならびに尿中 GLN排㴖量

Table 1に示すごとく，血中 GA 濃度は，対茝 では平均 6.4士1.1 mg/dlであるが，癌をその初 期・中期・本期癌とに区分測定すると，前者では $6.7 \pm 1.8$, 後者では $6.8 \pm 1.3$, 癌のち肪や 
Table 1. Glucuronic acid (GA) level in blood and glucuronide (GLN) content in urine patient with carcinoma and of normal control.

\begin{tabular}{|c|c|c|c|c|c|}
\hline & \multirow{2}{*}{ No. } & \multirow{2}{*}{$\begin{array}{r}\text { GA in blood } \\
(\mathrm{mg} / \mathrm{dl})\end{array}$} & \multicolumn{3}{|c|}{$G L N$ in urine $(m g / d a y)$} \\
\hline & & & Total-GLN & $F+N-G$ & $0-G$ \\
\hline Control & 10 & $6.4 \pm 1.1$ & $170.4 \pm 76.3$ & $6.5 .4 \pm 18.5$ & $105.0 \pm 41.6$ \\
\hline $\begin{array}{l}\text { Incipient and moderately } \\
\text { adranced } \mathrm{Ca} \text {. }\end{array}$ & 9 & $6.7 \pm 1.8$ & $253.9 \pm 111.8$ & $117.0 \pm 97.7 *$ & $136.9 \pm 74.2$ \\
\hline Advanced Ca. & 7 & $6.8 \pm 1.3$ & $458.6 \pm 266.9^{*}$ & $280.3 \pm 210.6^{*}$ & $172.3 \pm 89.0$ \\
\hline
\end{tabular}

* Statistically significant differences from normal values are indicated: $P=<0.01$

〉高值を示すと共に，ての進行度に平行するかの ごとくである加，むるん有意な差異ではない。

一方，尿中 GLN量については，対囬の総 GL $\mathrm{N}$ 平均 $170.4 \pm 76.3 \mathrm{mg} /$ dayにたいして，初期な らびに中期癌の総GLNは253.9土111.8，末期 癌は 458.6士266.9 亿著明に排泄增加を示す。 れを $\mathrm{F}+\mathrm{N}-\mathrm{G}$ ，および，O-G分画别にみる と, 雨分画共に, 癌の進行度に平行して增量する が，特心， $\mathrm{F}+\mathrm{N}-\mathrm{G}$ 分画の境加が著明である。 これらの增加汢対脆との間に，総 GLN（ $\mathrm{P}=$ $<0.01), \quad \mathrm{F}+\mathrm{N}-\mathrm{G}(\mathrm{P}=<0.01)$ および $\mathrm{O}-\mathrm{G}$

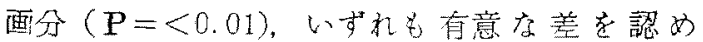
る。

II. GA䞨口頶荷害騷

1） GA経口負荷時の血中 $\mathrm{GA}$ 濃度

Table 2に示すごとく，G A 5 g 経口俱荷を施 すと，対照では 1 時間後に平均 $8.3 \pm 0.8 \mathrm{mg} / \mathrm{dl}$ と著明にGA濃度上景が見られ，子の後，次第 に低下して 6 時間日には $5.1 \pm 0.5$ 之前值に復 する。さらに，GAを1週間与えた後に顀荷試験
を施すと，前值において $6.1 \pm 1.3$ ，初回の民 れより当高值を示す。 GA負荷 1 時閒值は 9.4 土 1.6 と高く, その後の低下傾向も，初回急荷時に 此較して，や>緩徐ではあるが 6 㭙閒目には 5.5 \pm 1.1 と旧值に復する。

癌について，GA 5 g 負荷後の血中濃度をみる と，対㖹と異なり，変動はかなり不定である，個 マの例についての時間的消長差が大きく，特定の 上昇peakを示さない。こ饥に 1 週閐 $\mathrm{GA}$ 連用 せしめると，血中濃度のばらつきが少なくなる。 $\mathrm{GA}$ 負荷試験後の消長は低值ながら6時間にわた り李打上昇態度を示し続ける。

2） GA経口負荷時の尿中 G LN 量

Table 3に示守ごとく，GA経口負荷後の屁中 総GLN注，平均 $112.2 \pm 21.5 \mathrm{mg} / \mathrm{dl}$ 之約 2.4 倍 に堌加し，分画别に二れをみると， $\mathrm{F}+\mathrm{N}-\mathrm{G}$ は 3.8倍， $\mathrm{O}-\mathrm{G}$ は 1.6倍と前者の排泄濃度の与が 高い.1週間連用後については，や>総GLN増 加を示しはするが，有意な增量とは㒛められな い。これに，GA負荷試験を施すと，総GLN

Table 2. Changes of GA level in blood after oral administration of glucuronolactone $(5 \mathrm{~g})$.

\begin{tabular}{|c|c|c|c|c|c|c|c|c|c|c|c|}
\hline & \multirow{3}{*}{ No. } & \multicolumn{5}{|c|}{ Initial administration } & \multicolumn{5}{|c|}{ After administration for lweek } \\
\hline & & \multirow{2}{*}{ Before } & \multicolumn{3}{|c|}{ After $G A$ administr. } & & \multirow{2}{*}{ Before } & \multicolumn{4}{|c|}{ After $G A$ administr. } \\
\hline & & & 1 & 2 & 3 & $G(h+)$ & & 1 & 2 & 3 & $\sigma(h r)$ \\
\hline Control & 8 & $\begin{array}{r}m g / d i \\
5.1 \pm 0.9\end{array}$ & $8.3 \pm 0.8$ & $6.5 \pm 0.8$ & $59 \pm 0.4$ & $5, \pm 0,5$ & $6.1 \pm 1.3$ & $9.4 \pm 1.6$ & $89 \pm 1.0$ & $22 \pm 1.2$ & $5.5 \pm 11$ \\
\hline Carcinoma & 5 & $5.5 \pm 3.8$ & $6.2 \pm 3.1$ & $5.2 \pm 2.5$ & $6.6 \pm 2.4$ & $6.2 \pm 2.9$ & $4.3 \pm 1.0$ & $4.4 \pm 0.9$ & $4.7 \pm 1.9$ & $5.0 \pm 0.7$ & $5.5 \pm 1.3$ \\
\hline
\end{tabular}


Table 3. Changes of GLN concentration in urine after oral administration of glucuronolactone $(5 \mathrm{~g})$.

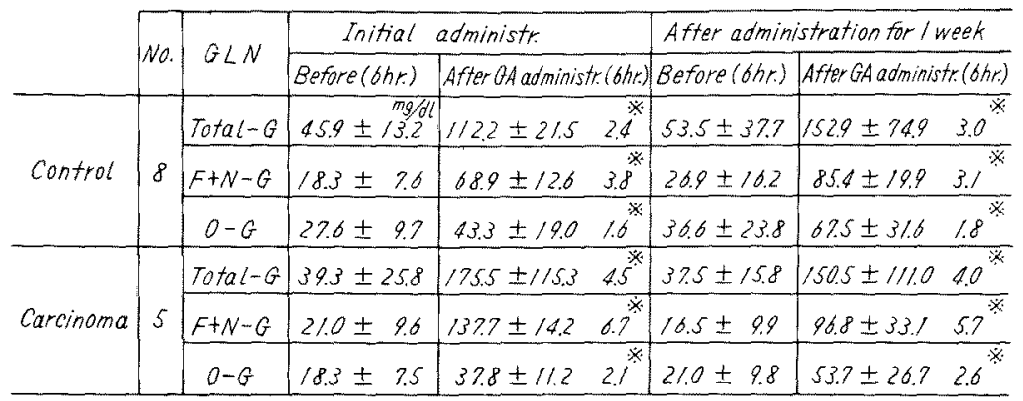

* Ratio between GLN after GA administr. : GLN before GA administration.

排泄は $152.9 \pm 31.6$ と約 3 倍の增量で, 初回負荷 時と大差を示さないが，分画別に吟味するとき は， $\mathrm{F}+\mathrm{N}-\mathrm{G}$ は減少傾向示すが， $\mathrm{O}-\mathrm{G}$ 画分 分，むしろ初回上りも排泄堌加走示して注目され る。

癌においては、GA急荷娞の展中総GLNの消 長は $175.5 \pm 115.3$ 之約 4.5 倍に増加し, 対照の 专れに比較して，著明存排泄増加が見られる，画 分別には $\mathrm{F}+\mathrm{N}-\mathrm{G}$ 抢よび $\mathrm{O}-\mathrm{G}$ 画分共に前値にた いして，それそれ6.9倍㧍よび2.1倍と増量する が，特にF+N-Gの增加が著しい，GA連用後 に法，総GLN排渵量注37.5土15.8と初回のそれ 上変らない分，分画别にみると， $\mathrm{O}-\mathrm{G}$ 画分にお いて軽度增量認好る。っで，GA負街施す と, 総GLNの增加率は 4 倍程度で, 連用前より むしろ低く、刘鹏での排泄態度に近つく、分画别

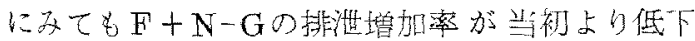

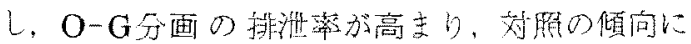
一致する。

\section{GA非経口負荷実験}

1) $\mathrm{GA}-\mathrm{Na}$ 静脄注射特の血中 $\mathrm{GA}$ 濃度

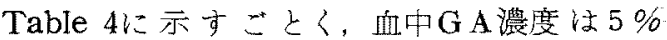
GA-Na $500 \mathrm{ml} 1$ 時間内に静注すると，そ心直 後において前值平均 $6.4 \pm 1.1 \mathrm{mg} / \mathrm{dl}$ 加ら $82.0 \pm$ 5.5 に舅し，さらに，1時間後には43.4土8.7 上低下する。1 週間静注連用後の空腹時血中濃度

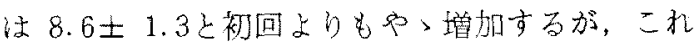
に GA 負荷を施しても，血中斐度の消長は初回轧 与時上大体同様の経過に終始する。

一方，癌における空腹時血中 $\mathrm{GA}$ 濃度は，これ まで同様，対照よりもわずかに亮值を示す，GA一 $\mathrm{Na}$ 負荷直後の血中濃度注平均 $58.5 \pm 10.0$ 己著明 に增加す百名，对照上りも明らかに上昇率が低 い。さらに，1時間後の血中 $\mathrm{GA}$ 濃度においても $37.7 \pm 10.6$ と対照より低值を示す.1週間連続注

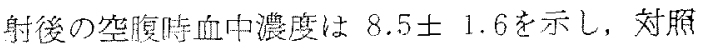
同様，GA尰用前よりも增加するが。これにGA

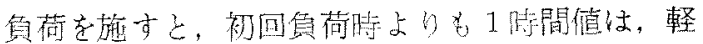

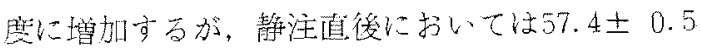
と対盟での上昇よりも低值を示す。

Table 4. Changes of $\mathrm{GA}$ level in blood after intravenous administration of sodium glucuronate (5\% Sol., $500 \mathrm{ml}$ ) for one hour.

\begin{tabular}{|c|c|c|c|c|c|c|c|}
\hline & \multirow[b]{2}{*}{ No. } & \multicolumn{3}{|c|}{ Initial administr. } & \multicolumn{3}{|c|}{ After GA administr. for l week } \\
\hline & & Before & $\begin{array}{c}\text { immed atter } \\
G A \text { inj. }\end{array}$ & $\begin{array}{c}\text { Thr.after } \\
\text { GA inj. }\end{array}$ & Before & $\begin{array}{l}\text { immed after } \\
\text { GA inj. }\end{array}$ & $\begin{array}{c}\text { the after } \\
\text { of inj. }\end{array}$ \\
\hline Contro! & 5 & $\begin{array}{r}m 9 / d \\
6.4 \pm 1.1\end{array}$ & $82.0 \pm 5.5$ & $43.4 \pm 8.7$ & $8.6 \pm 1.3$ & $81.7 \pm 99$ & $46.0 \pm 7.6$ \\
\hline Carcinoma & $?$ & $6.8 \pm 1.3$ & $58.5 \pm 10.0$ & $37.7 \pm 10.6$ & $8.5 \pm 1.6$ & $57.4 \pm 10.5$ & $400+101$ \\
\hline
\end{tabular}




\section{2) GA-Na静脈注射時の尿中 GLN濃度}

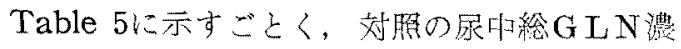
度注平均 $11.5 \mathrm{mg} / \mathrm{dl}(8.0 \sim 10.3)$ であるが，静 注㨁徭の総GLN澧度は 2686.9 (1782.5 3410.0) と著塯し，さらに，1洔間後にはいっ そう増加する. 1 週間速続静注徯のGA-Na負荷 前尿中 GLNは38.0（10.4〜54.0）で初めの艺れ よりる堌加している。これにGA-Naを真荷する 之, 静注直後に法, 初回魵荷㭙上的毛明らか汇高 濃度であるが，さらに，1時間後の排泄濃度は著 明に低下し，急速存排泄が営まれるものつごとく である。

$\mathrm{F}+\mathrm{N}-\mathrm{G} ，$ および，O-G分画别にこれを見

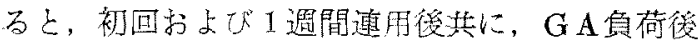
には， $\mathrm{F}+\mathrm{N}-\mathrm{G}$ 排浔が多いが，O-G分画につ いても排泚增加が認奻られる。

一方，癌の存中総 $\mathrm{GLN}$ 濃度注平均 $30.0 \mathrm{mg} / \mathrm{dl}$ （10.0〜51.3）上対照より高值を示すが，二れに GA-Na真荷すると，静注直捘には平均 2194.8 $\mathrm{mg} / \mathrm{dl}(1459.5 \sim 3537.0)$ 已著明に増加するが, 対照はごには增量し度い。さらに，1时間徯につい ては平均 $2853.5 \mathrm{mg} / \mathrm{dl}(1464.3 \sim 3669.6)$ で静注 直後よりも高値を示すが，な抢㸚照よりも低值に 止まる。
しかし，1週間連続後の負荷前值は平均 124.8 $\mathrm{mg} / \mathrm{dl}(22.0 \sim 370.5)$ て対照よりも著明に高 く,これにGA-Na負荷を行疛う之静注直後には， 平均 $2632.8 \mathrm{mg} / \mathrm{dl}(1300.7 \sim 3910.7)$, さらに, 1 時間後には平均 $3398.2 \mathrm{mg} / \mathrm{dl}(1647.0 \sim 47461)$ 上，明ら加に初回時上りも排泄増加を示し，对照 の排泄態展に近づく.

これを $\mathrm{F}+\mathrm{N}-\mathrm{G}$ 㧍よび $\mathrm{O}-\mathrm{G}$ 分画別にみると。 刘照同様, $\mathrm{GA}$ 負荷後には $\mathrm{F}+\mathrm{N}-\mathrm{G}$ 分画が著明に 嬶量するが，O-G分画にも堷加が認められる。 初回 $\mathrm{GA}$ 筫荷時と GA 連用徯負荷㭙の対比では, 特に，対炤よりも，癌ではO-G画分の増加が著 明存印象をうける。

念のため、これを原量に上つて絶対量に換算京 ると Table 6のごとく，癌では GA 連続投与前 徭を通じGA負荷試験にさいしては，対䳟よりも GLN排澌が少ない結果を示す。

さらに，日を追つて4日目までの尿中 GLN排

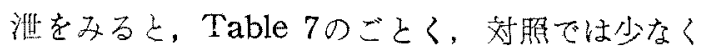
とも3日目には旧值に復するが，癌については4 日目以後に㧍いても，なお，前值の1.6倍前後の 高澧度を示し，GLNの排泄荤延を推測せしめ る。

VI. GA-Na静脈注射時における血中諸成分の

Table 5. Changes of GLN concentration in urine after intravenous administration of solium glucuronate $(5 \% \mathrm{Sol}, 500 \mathrm{ml})$ for one hour.

\begin{tabular}{|c|c|c|c|c|c|c|c|c|}
\hline & \multirow{2}{*}{ No. } & \multirow{2}{*}{$G \angle N$} & \multicolumn{3}{|c|}{ Initial administration } & \multicolumn{3}{|c|}{ After $G A$ administr for I week } \\
\hline & & & Before & immedaft $G A$ ing & thr. aft $G A$ ing. & Before & immed aft $G A$ inj. & thr. aft GA inj. \\
\hline \multirow{3}{*}{ Control } & \multirow{3}{*}{5} & Total $-G$ & $\begin{array}{l}11.5^{m g / d t} \\
80 \sim 10.3\end{array}$ & $\begin{array}{c}2,686,9 \\
1,782.5 \sim 3,4100\end{array}$ & $\mid \begin{array}{c}3,552.2 \\
3,141.9 \sim 4,085.8\end{array}$ & $\begin{array}{c}38.0 \\
10.4 \sim 54.0\end{array}$ & $\begin{array}{c}2,917.8 \\
1,940.6 \sim 3,366.6\end{array}$ & $\begin{array}{c}3,339.4 \\
2,796.2 \sim 3,820.4\end{array}$ \\
\hline & & $F+N-G$ & $3.9-6.2$ & $\begin{array}{c}2286.2 \\
1317,5 \sim 2994.6\end{array}$ & $\begin{array}{c}2,782.3 \\
2,441.3 \sim 3,3666\end{array}$ & $\begin{array}{c}29.4 \\
6.4 \sim 39.8\end{array}$ & $\begin{array}{c}2,3 / 8.2 \\
1,432.2-2703.2\end{array}$ & $\begin{array}{c}2,6,04.5 \\
2,287.8 \sim 3,57.0\end{array}$ \\
\hline & & $O-G$ & $\begin{array}{c}6.4 \\
3.9 \sim 10.4\end{array}$ & $\begin{array}{c}400.7 \\
217.0 \sim 542.0\end{array}$ & $\begin{array}{c}269.9 \\
799.8 \sim 861.0\end{array}$ & $\begin{array}{c}8.6 \\
4.0 \sim 14.2\end{array}$ & $\begin{array}{c}599.6 \\
4650 \sim 787.4\end{array}$ & $\begin{array}{c}634.9 \\
4588 \sim 942.4\end{array}$ \\
\hline \multirow{3}{*}{ Carcinoma. } & \multirow{3}{*}{7} & Total $-G$ & $\begin{array}{c}30.0 \\
10.0 \sim 513\end{array}$ & $\begin{array}{c}2.194 .8 \\
1.459 .5 \sim 3.5370\end{array}$ & $\left|\begin{array}{c}2.853 .5 \\
1,464.3 \sim 3.6696\end{array}\right|$ & $\begin{array}{c}124.8 \\
22.0 \sim 370.5\end{array}$ & $\begin{array}{c}2.632 .8 \\
1,300.7 \sim 3,910.7\end{array}$ & $\mid \begin{array}{c}3.398 .2 \\
1.647 .0 \sim 4746.1\end{array}$ \\
\hline & & $F+N-G$ & $\begin{array}{c}13.5 \\
2.0 \sim 19.3\end{array}$ & $\begin{array}{c}1.672 .7 \\
1.0075 \sim 3.240 .0\end{array}$ & $\begin{array}{c}2.193 .2 \\
1.348 .5-3,171.3\end{array}$ & $\begin{array}{c}99.1 \\
11.0-333.0\end{array}$ & $\begin{array}{c}2,063.6 \\
1,0900 \sim 3,182.2\end{array}$ & $\begin{array}{c}2,563.1 \\
1,35000-3,253.5\end{array}$ \\
\hline & & $O-G$ & $\begin{array}{c}10.5 \\
8.0 \sim 32.0\end{array}$ & $\begin{array}{c}522.1 \\
2970-793.5\end{array}$ & $\begin{array}{c}660.3 \\
291.0 \sim-1193.5\end{array}$ & $\begin{array}{c}25.7 \\
9.8 \sim 51.2\end{array}$ & $\begin{array}{c}569.2 \\
217.0 \sim 886.6\end{array}$ & $\begin{array}{c}835 \\
2970 \sim 1229.8\end{array}$ \\
\hline
\end{tabular}


Table 6. Changes of GLN content in urine after intravenous administration of sodium glucuronate $(5 \%$ Sol., $500 \mathrm{ml})$ for one hour.

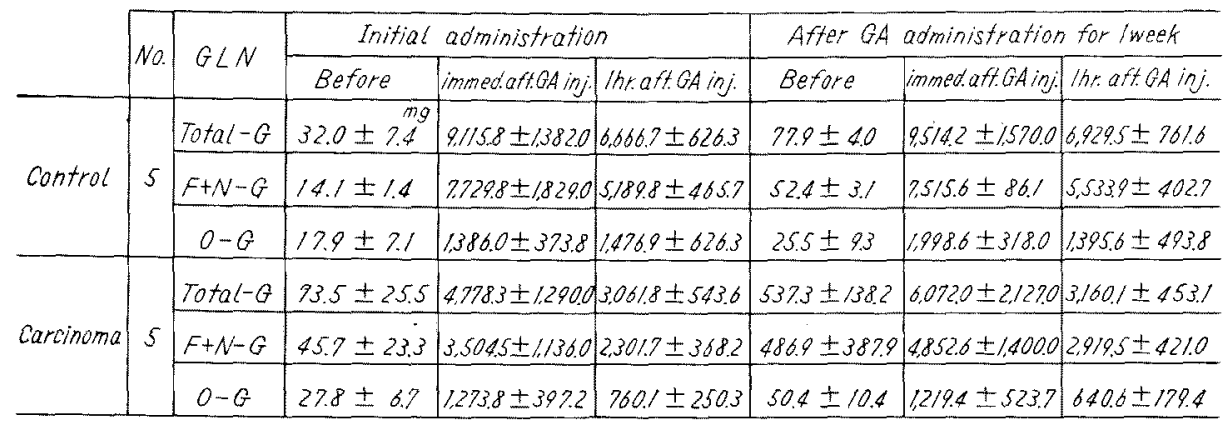

Table 7. Changes of daily GLN content in urine after sodium glucuronate injection ( $5 \%$ Sol., $500 \mathrm{ml}$ ).

\begin{tabular}{|c|c|c|c|c|c|c|c|c|}
\hline & \multirow{2}{*}{$G L N$} & \multirow{2}{*}{$\begin{array}{l}\text { Before GA } \\
\text { administr.(a) }\end{array}$} & \multicolumn{6}{|c|}{ After GA administr. } \\
\hline & & & End day $(b)$ & $b / a$ & $3 r d$ day $(c)$ & c/a & 4th day $(d)$ & $d / 0$ \\
\hline \multirow{3}{*}{ Control } & Total-G & $200.5^{\mathrm{mg}}$ & 316.4 & 1.6 & 241.5 & 12 & $\therefore$ & - \\
\hline & $F+N-G$ & 92.5 & 156.8 & 1.7 & 114.0 & 1.2 & $\therefore$ & : \\
\hline & $0-G$ & 108.0 & 159.6 & 1.5 & 127.5 & th & $\therefore$ & 二 \\
\hline \multirow{3}{*}{ Carcinoma } & $10+a b-G$ & 1161.0 & $2,005.0$ & 1.7 & 1932.9 & 1.6 & 1.893 .6 & 1.6 \\
\hline & $F+N-G$ & 975.0 & $1,800.0$ & 1.8 & 1.6240 & 1.6 & 1.538 .0 & 1.6 \\
\hline & $O-G$ & 186.0 & 205.0 & It & 3080 & 1.6 & 355.6 & 1.9 \\
\hline
\end{tabular}

変化

1）GA-Na静脈注射封の血清N P N について

Table 8に示すごとく，健康詨照においても，

GA-Na負荷後には，一時的に軽度のN PN低下
を示し、この傾向は $\mathrm{GA}$ 連用前後を通じて变らな い.しかし，この低下注，いずれも推計学的には 有意で存い。

一方, 癌の N P N

Table 8. Changes of NPN and of urea concentration in sera after intravenous administration of sodium glucuronate ( $5 \%$ Sol, $500 \mathrm{ml}$ ) for one hour

\begin{tabular}{|c|c|c|c|c|c|c|}
\hline & & \multirow{2}{*}{ No. } & \multicolumn{2}{|c|}{ Initial administr. } & \multicolumn{2}{|c|}{ After GA administr for lweek } \\
\hline & & & Before & thr aftoding. & Before & thr aft GA inj. \\
\hline \multirow{2}{*}{$\begin{array}{l}N P N \\
(m g / d t)\end{array}$} & Control & 3 & $32.7 \pm 0.6$ & $285 \pm 68$ & $30.2 \pm 6.0$ & $24.4 \pm 30$ \\
\hline & Carcinoma & 5 & $33.7 \pm 7.7$ & $29.4 \pm 2.0^{*}$ & $29.2 \pm 4.3$ & $26.4 \pm 4.2$ \\
\hline \multirow{2}{*}{$\begin{array}{l}\text { Urea } \\
(m g / d)\end{array}$} & Control & 5 & $17.6 \pm 2.5$ & $14.4 \pm 2.9 *$ & $16.6 \pm 4.4$ & $149 \pm 1.8$ \\
\hline & Carcinama & 7 & $22.2 \pm 4.2$ & $19.1 \pm 2.6 *$ & $19.8 \pm 40$ & $18.2 \pm 3.6$ \\
\hline
\end{tabular}

Statistically significant differences from values before $G A$ administration are indicated: $* \mathrm{P}<0.05$

$* * \mathrm{P}<0.02$

$* * * \mathrm{P}<0.01$ 
艺示すが，GA-Na静注後には29.4土7.0と低下 し、この差は有意 $(\mathrm{P}=<0.05)$ と判定される.

GA 連用後には29.2土4.3と，空腹時に打いて明 らかな低下を示す。この段階て $\mathrm{GA}$ 負荷を行なう と，さらに，低下するが，有意差とは認められな W.

つまり GA-Na静注により N PN値の低下をき たすが，只の低下作用は癌にすいて，より著明と いえる。

2）GA-Na静脈注射時の血清 ureaについて

Table 8に示すごとく, 対煦の血清urea值は平均 $17.6 \pm 2.5 \mathrm{mg} / \mathrm{dl}$ を示すが， GA 僨荷後には14.4 士2.9 上有意に低下し， 1 週間 $G A$ 連用後には， 空腹時に $16.6 \pm 4.4 \mathrm{mg} / \mathrm{dl}$ 上，初回のそれより当 わすが低下する。こつで $\mathrm{GA}$ 負荷を行なうと， 1 時間後には，さらに，14.9土1.8と低下するが 有意ではない。

これを癌についてみると，筀腹時には22.2土 4.2 と対煦より高值を示 L, GA負荷後には19.1土 2.6 と有意な低下を示す。1週間 G A 連用後の前 值は19.8土4.0七初回のを机より娄低く，二の間 の美は有意である。こンでGA負荷を行なうと， さらに18.2土3.6と低下するが，前值との間の差
は有意とはいえない。

つまり対兔・癌共に，GA-Na静注に上り血清 urea值の低下を認める。

3） GA-Na静脈注射時の血中ammonia檤につ w

Table 9に示すごとく, 対照の空腹時血中ammonia值は，GA負荷によつても活とんど低下し ない。しかし，1週閶GA連用後には，前值と $\mathrm{GA}-\mathrm{Na}$ 静注後 1 時間値との間に有意の低下をき たす。

癌における血中ammoniaは一般に，対唱より 高值を示す場合怔多いが，これに G A 静注する と，明ら加に低下し，その差は有意 $(\mathrm{P}=<0.01)$ である、GA1週間連用後についても，同様に有 意の低下を示す。

特に， $100 \mathrm{r} / \mathrm{d} \mathrm{l}$ 以上の高值を示す場合と，それ 未満の場合別に区分観察すると，前者において は, 初回 $\mathrm{GA}$ 負荷々 1 週間 $\mathrm{GA}$ 連用後のGA負荷 と共に，それそれの前值に比較して有意の低下を きたすが，後者はGA連用 1 週間後のGA負荷試 験においてのみ有意に低下する（ $\mathbf{P}=<0.02 ）$.

念のため $5 \%$ glucose $500 \mathrm{ml}$ 静注したさいの 血中ammonia值を調べたが，むしろ軽度な增量

Table 9. Changes of ammonia concentration in blood after intravenous administration of sodium glucuronate $(5 \%$ Sol., $500 \mathrm{ml})$ and $/$ or of glucose $(5 \%$ Sol., $500 \mathrm{ml}$ ) for one hour.

\begin{tabular}{|c|c|c|c|c|c|c|}
\hline & \multirow{2}{*}{ No. } & \multicolumn{2}{|c|}{ Initial administr. of $G A$} & \multicolumn{2}{|c|}{ After $G A$ administr. for lweek } \\
\hline & & & Before & Thr. aft. GA inj. & Before & Ihr.aft. GA inj. \\
\hline \multicolumn{2}{|c|}{ Control } & 7 & $87 \pm 16^{7 / d 6}$ & $81 \pm 9$ & $94 \pm 8$ & $66 \pm 19^{*}$ \\
\hline \multicolumn{2}{|c|}{ Carcinoma } & 25 & $107 \pm 37$ & $86 \pm 34^{* * *}$ & $98 \pm 41$ & $78 \pm 27^{* *}$ \\
\hline \multirow{4}{*}{$\begin{array}{r}5 \\
\text { s } \\
\text { s. } \\
\text { s } \\
0 \\
\end{array}$} & $\geq 100 \% / d$ & 16 & $130 \pm 27$ & $100 \pm 28^{* * *}$ & $125 \pm 32$ & $90 \pm 19^{* *}$ \\
\hline & $<100 "$ & 16 & $74 \pm 17$ & $69 \pm 18$ & $72 \pm 23$ & $64 \pm 24^{*}$ \\
\hline & & NO & \multicolumn{2}{|c|}{ Initial administr. of glucose } & \multicolumn{2}{|c|}{ After glucose adminjstr. for I week } \\
\hline & & & Before & Iht aft. Glucose in & Before & Whatt Glucose inj \\
\hline \multicolumn{2}{|c|}{ Carcinama } & 3 & $95 \pm 2$ & $109 \pm 6$ & $79 \pm 1$ & $90 \pm 10$ \\
\hline
\end{tabular}

Statistically significant differences from values before GA administration are indicated: $* \mathrm{P}<0.02$

$$
* * \mathrm{P}<0.01
$$


を示した。

加〉る高 ammonia 血淀にたいするGAの低 下作用には，その直接結合を推測されるところか ら，䀒疾㭧時にみられる高 ammonia血の梨度别 に, in vitroに GA 加 え, $37^{\circ} \mathrm{C} 1$ 時閒incubate してこれを測定した。すなわち Table 100ごを く，高ammonia血の 2 例は，共にその低下を示 したが，此較的ての程度の低い例では変化がな く，臨床結果之同様に血中 ammoniaの高い場合 汪ど低下が著明であることが判明した。

V. GA-Na静㟲注射時における血清 $\beta$-glucuronidase $(\beta-G)$ 活性

Table 11にみるごとく，健康対脸に抒いても

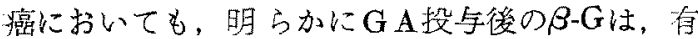

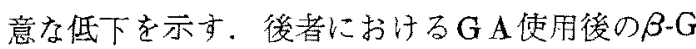
活性低下率住79.7\%で対照よりも著しい。むろん GA 1 週間連用後の早朝血中活性に㧍いても軽度 に低下するが，二の状龍に GA 静注を施すと，1 時間後には，より著明に活性低下をきたす。これ を $\beta$-Gの高活性群（1500 unit/dl以上）と低活性 群（1500 unit/dl以下）に分けて比較すると，わ ずかに，高活性群での低下の方が著明である。陚 みに, glucose投与を行なつたが、このときも，軽 度に活性低下がみられた。
Table 10. Changes of ammonia concentration in blood after addition of sodium glucuronate (in vitro examination).

\begin{tabular}{c|c}
\hline $\begin{array}{c}\text { Blood }(2 \mathrm{ml}) \\
+ \text { Soline }(0 . \mathrm{m} l)\end{array}$ & $\begin{array}{c}\text { Blood }(2 \mathrm{ml}) \times \\
+10 \% 64-1 \mathrm{ma}(0 . \mathrm{ml})\end{array}$ \\
\hline $360 \% \mathrm{dl}$ & 335 \\
\hline 380 & 277 \\
\hline 135 & 140 \\
\hline
\end{tabular}

* incubated at $37^{\circ} \mathrm{C}$ for $1 \mathrm{hr}$.

VI．癌患者永エキスのTxe作用に攻はすすA投 与の影響

1）癌展エキスのTxh作用とGA投与の影響

Fig. 1 に示すごとく, マウスを 5 群に分けて以 下の害験を試みた。

（a）対炤群について：第 1 群40匹の䀒catalase(以下cat. と略す) 活性は本飼烱条件下におい ては 22.06〜 32.94, 平均 28.42 上比較的変動加 少なく，実駼に適するものと認められる。

こ〉に扔いて，健康対照尿 エキス（NUEx） 2 mg注射の影響をみると，17.83〜 31.30, 平均 24.14 と，無処置対照よりも僅汃に低下を示すに 過ぎないない。

(b) 癌㞗エキス（CaUEx）注射群について：

Table 11. Changes of serum B-glucuronidase activity after intravenous administration of sodium glucuronate and/or of glucose for one hour.

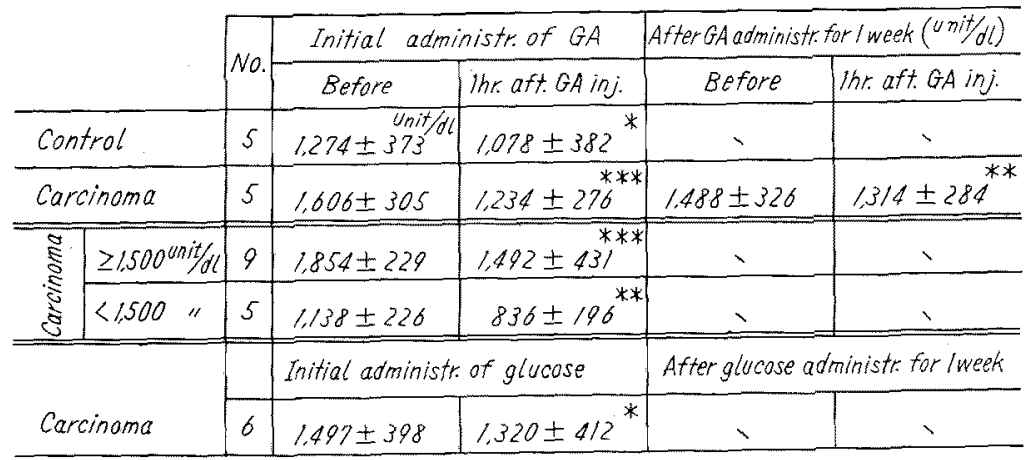

Statistically significant differences from values before $\mathrm{GA}$ and/or glucose administration are indicated: $* \mathrm{P}<0.05$

$* * \mathrm{P}<0.02$

$* * * \mathrm{P}<0.01$ 


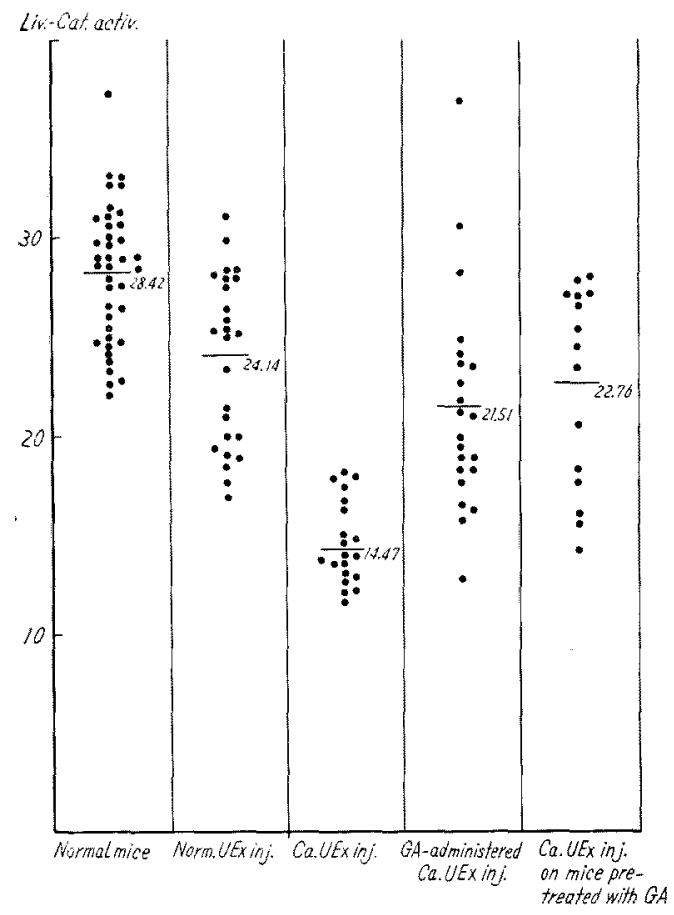

Fig. 1. Effect of GA administration upon mouse liver catalase-activity inhibiting action of urinary extracts from patients with carcinoma.

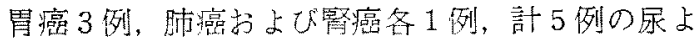
り抽出したCaUExそれぞれ 2 何を注射したさい の肝cat. 活性注10.28 18.22, 平均 14.47 , 対 臊に比較して昭ら加に低下し，NUEx群との間に は，推計吟味上有意差言翏める $\left(\chi^{2}=29.06\right.$, $\mathrm{P}=<0.01$ ).

2）ＧA大量連用後の癌尿エキ又注射群につい $\tau$

上記同一対像に，GA投与去施した 1 週間後の

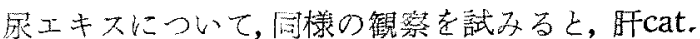
值は 12.77〜 37.01，平均 21.51を示し，明ら加 にCaUExの䀒cat.活性阻害作用が抑制される $\left(\chi^{2}\right.$ $=14.9, \quad \mathrm{P}=<0.01$ ).

3）あらかじめGA投与を施したマウスにたい するCaUEx注射群について

GA50mg，4 日間腹腔内注射を施したマウスに， (b) 項同様に, CaUExを注射して䀒cat. 活性 を測定すると，14.43〜 28.22，平均 22.76を示 す。無処置マウスにCaUEx学注射した群との間 には，有意の差がみられ，䀒cat.阳害作用が㧕制 されるもの〉ごとくである。

4）癌尿エキスの二, 三化学組成について

Table 12に示すごとく，Txh作用を示す癌尿 エキスに含まれる G A 量は，Txh作用を欠く健康 対照尿エキスのそれよりも，明ら放に增量する $(\mathbf{P}=<0.01)$. しかし, tyrosinjよびhexose量 には有意の差異を䛱めない。

か〉る癌息者に，以上のごとく，GA投与を施 して尿エキスをとると，化学組成上には，期待し たほどの差異を示さない。

\section{総括ならびに考案}

癌にお计る GA代謝は，その血中・展中濃度の 消長, 特に, 癌の進行度との関倸からみて, 正常 よりも京進しているものと考えられる，換言すれ ば，G.A需要が增加していることが推測される.

これを体外上り大量に与えた $\mathrm{GA}$ の消長面から 推測すると，癌䓌者では血中・尿中心ずれの濃度

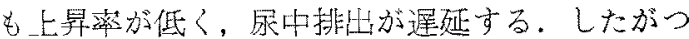
て，与えられたGAは体内のいずれかに停檪利用 され当ものと考えざる得宗い。

Table 12. Several chemical constituents in urine extract (VEx.).

\begin{tabular}{|c|c|c|c|c|c|}
\hline & & $\mathrm{H} \times \mathrm{u} \quad(\mathrm{mg} / 100 \mathrm{mg})$ & Tyr $(\mathrm{mg} / 100 \mathrm{mg})$ & Hxs $(m g, 100 m g)$ & Txh-effect \\
\hline & rmal UEx. & $1.27(0.76-2.25)$ & $4.45(4.40 \sim 4.50)$ & $13.4(13.1-13.7)$ & - \\
\hline & Before GA administs & $1.94(148 \sim 2.45)$ & $5.25(5.20 \sim 530)$ & $11.5(113 \sim 11.7)$ & \# \\
\hline Ca.UEX. & ouring $G A$ administr. & $1.76(1.53 \sim 1.90)$ & $4.85(4.75 \sim 4.95)$ & $11.4(10.8 \sim 11.9)$ & + \\
\hline & Wwek aft. GA administr. & $1.20(0.85 \sim 1.56)$ & $4.60(4.25 \sim 4.95)$ & $10.1(8.7-11.4)$ & $H$ \\
\hline
\end{tabular}




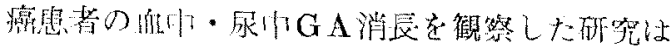

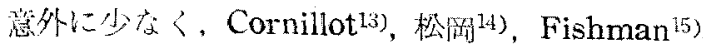

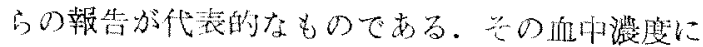

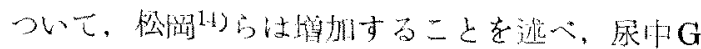
LNについては, Cornillot ${ }^{15}$ 况癌全般での增量

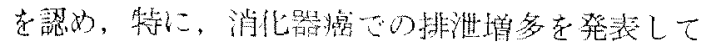
いる.

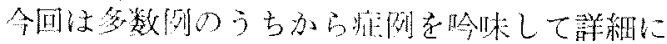
観祭したが，大体，二机らの成績に一致す号結果 老得た。特に，胃癌を主な刘集とした点加号考察

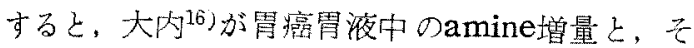
のTxh的作用を報告 し，また，Stevenson 17)らが GLN合成は腎および胃腸管において，活発に営 まれることを說いていることも見逃すことができ ない、いずれにしても癌における代謝異常には， 当然いろいろなaglucuronの発生が考えられ，こ れが $\mathrm{GA}$ 需要增加を招き，また，瓜中GLN熄加 を来なすことが推測される。

このことは，体外からGAを与えたさいに，経

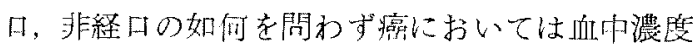

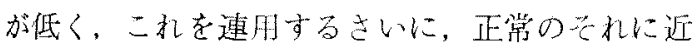
づくことによっても寒つけられるし，尿印 GLN の排泄態度にみら机る变化加らも首肯される。む ろん体外方与大量にGAを与えることの意義を㥜 らかにしようとすれば，同將に，卆れが内因性 $\mathrm{G}$ A 代謝過程に如何なる影稡を寺えるかについても 考虑せ权ばなるまい。

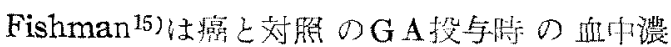

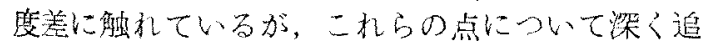

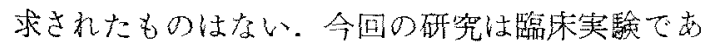
り，それらの詳細を究明することは不可能である 加，それ之関連して原中GLNの分画観祭と二， 三の血咽子小の影溉面を合わせ調查した。すな b方，体外上り GA投与行なう辰中 $\mathrm{F}+\mathrm{N}$ $\mathrm{G}$ 画分， $\mathrm{O}-\mathrm{G}$ 画分いずれもが增多を示す。前者 の中には，当然，遊離 $\mathrm{GA}$ 多多く含京机上うが， 後述のごとく, N-G形成を裏づける現舜からみ ると，一庥は二れ㥙 $\mathrm{GA}$ 代謝改善面に值接・間接 的に利用されることを考えさせる。この点を。

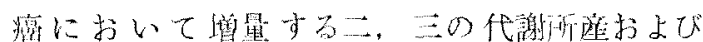

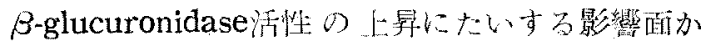

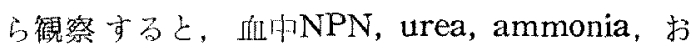
よひア 明ら加正常值入上近つく事实琶的た。

蛋白簧化作用の增進主石滛において，血清 N P N㧍よびurea汃塯量することは周知のごとくで

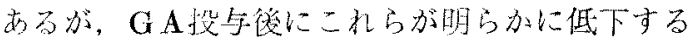
と些に，血中ammonia 女有意な低下存示すこと は，石館17のamine抱合をはじめとするN-GLN 形成の事実を裏畫きするものといえよう。念のた め，試験管内に损いて GA を添加したさいの血中 ammoniaの消長を観察すると，これが高濃度の さいには，減少するから，直結結合の可能性も 否定することはできない。しかし，体内に㧍ける その低下事はいっそうと著明であり，GAの生体 内に打应作用機序には，なお，複雑な過程汸関 与するもの上推測される。いずれにしても体外か

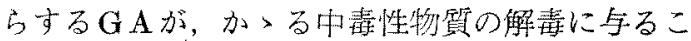

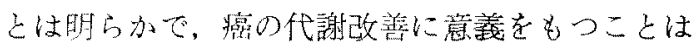
否めまい。

また，血清队-glucuronidase活性がGA投与に より低下することはFishman15によつても認め られているが，その機序にかんしては明らかでな い.今回はglucose具荷によつても多少活性が低下 することを諗めたが，このことは，四を介する影

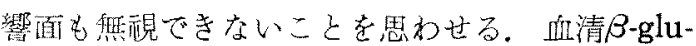

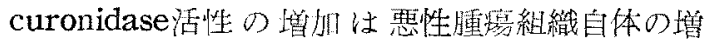
殖過程上直接関連するとされており，むるいは， GAが腫㾤の代謝過櫫に介人するなんらかの結果

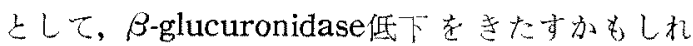
ないが憶測の域老㟔ない。

以上の知兒を通じて，担癌生体にみられる

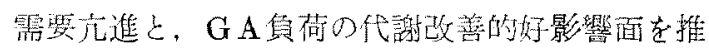

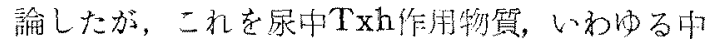
川癌尿王キスの生体作用にたいする影響面にすい てみても，その解毒効果を期侍できる結果を得 た。

癌尿工キ,久のGA含量が，比較的健康対得尿工 
キスのそれよりも多いことは，既報11されたとこ

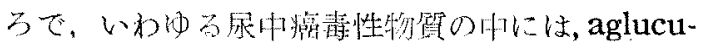
ronとして含まれるものの存柆が多分に推測さ れる.

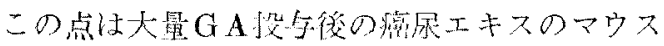

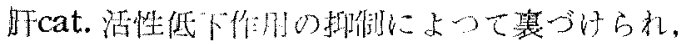

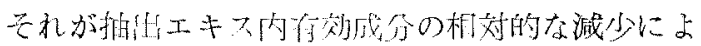
るものでなととは、三，三化学組成の測定結果 からも，また，動物に注射与るさいの量的配分に よっても確かにされた。

さらに，あらかじめ，マウスに充分量のGA投

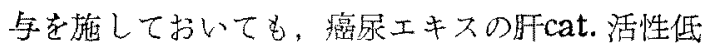
下を防止できたが，このことからも，体外から投

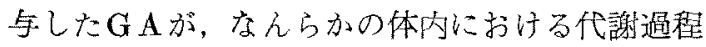
に好影響を及㴗し，只れによつて，癌毒性物質の 中和解毒が営まれることが考えられる。また，シ フテリア粗毒素が， GAによりトキソイド化され るさいには, 摰素の官能基たるアミノ基のN-GLN

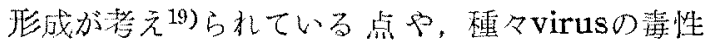
が，同様GLN形成によつて俩毒化されるとの報

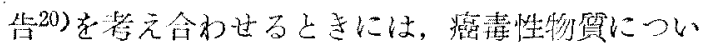
てもGLN形成に上る值接的の解毒機序加考无ら れないでもない。いずれにしても，この奏効機序 の詳細はな招明らかでない。

\section{結論}

担㾤生体にみられる代謝異常改善を目的として 研究孝進めるにあたり，glucuronic acid代蔐に おけ方变化を迫求古万与共に，GA金量の多心癌
尿巾Txh様毒性物質の解毒・中和を意図した。

担癌生体においては，明ら彔に，GA需要の方 淮が推测されると期に，二れに体外上り大量の $\mathbf{G}$ A ( $5 \%$ sodium glucuronate, 500ml) 与える ときは，二三の中閵代謝変化の修正をきたし，

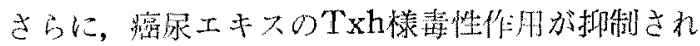

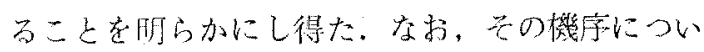
て二，三の孝祭を加えた。

(本研究恃交部省科学研究費打上び東京生化学研究 会よりの助成金交付をらけて行なわれたるのである）。

\section{文献}

1) 中原 - 福田 : Jap. Med. J., 1, 271 (1948). -2) 中川・笠井：日内会誌，40，312(1951)。一-3)䒿橋： 札医誌，11，373(1957)。一- -4) 佐滕：札医誌, 19, 96 (1961). -5) 新保: 札医誌，21，121 (1962). -6) 石館他：桨学誌, 79, $843(1959)$. -7) 石 餚-南原 : Reports on the study of glucuronic acid (Abstract) p. 1 (1956). -8) Dische, Z.: J. Biol. Chem., 167, 189 (1947). -9) Seligson, D. \& Hirahara, K.: J. Lab. \& Clin. Med., 49，962（1957），一10）塚元：醋素研究法，4，760 (1961). -11) Fukuda, M.: Sapporo Med. J., 14., 250 (1958)，一12) 小营：医学々生物兴，31，5 (1954). - 13) Cornillot, P.: Clin. Chim. Acta, 7, 42 (1962)。 - -14) 松岡他: 第 4 回グルクロン酸研 究会報告集，p. 58 (1958)，一15) Fishman, W.H.: J. Clin. Invest., 30，685 (1951)。-16) 大内他: 第21回日本癌学会 (1962). - -17) Stevenson, I.H., et al.: Biochem. J., 82, 330 (1962), -18) 石館: 第 5 回グルクロン酸矿究会報笲策， p. 67 (1959).

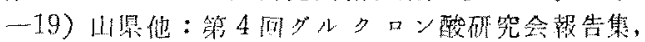
p. 85 (1958)，一-20) 後落：籍 5 问グルクロン酸研 宽全硍告集， p. 40 (1959). 